\title{
RESEPSI MASYARAKAT TERHADAP PESAN HALAL PADA IKLAN FRESHCARE
}

\author{
Nurma Tri Amalia ${ }^{1}$, Indah Wenerda ${ }^{2}$ \\ Universitas Ahmad Dahlan Yogyakarta \\ Email.nuermaamalia765@gmail.com
}

\begin{abstract}
ABSTRAK
Subjek yang digunakan dalam penelitian iklan FreshCare ini membicarakan mengenai pesan - pesan yang terkandung dalam iklan. Awalnya iklan FreshCare ditayangkan oleh Brand Ambassador Agnes Monica kemudian digantikan oleh Brand Ambassador Dewi Sandra, yang menampilkan bahwa FreshCare lulus sertifikasi Halal dengan menunjukkan serta menjelaskan keberadaan label Halal didalam iklan tersebut. Dengan demikian penelitian ini dilakukan untuk mengetahui penerimaan masyarakat terhadap pesan Halal tersebut. Sasaran narasumber yang digunakan pada penelitian ini adalah sebagian besar masyarakat di Yogyakarta. Secara teoretis penelitian ini ingin mengetahui reaksi masyarakat terhadap penerimaan pesan Halal yang terkandung dalam iklan FreshCare yang menjelaskan mengenai produk dan kehalalan produk dengan menampilkan label Halal oleh MUI (Majelis Ulama Indonesia). Mengungkapkankeberadaan pesan Halal dalam iklan FreshCare terhadap penerimaan pesan masyarakat diYogyakarta, berbagai macam penerimaan pesan yang terbagi dari beberapa tipe dan metode kesimpulan akan diteliti dengan metode deskriptif kualitatif dengan kumpulan iklan FreshCare versi Agnes Monica, Dewi Sandra serta kedua duanya. Pengumpulan data dilakukan dengan metode wawancara mendalam, dokumentasi, catatan, serta perekam suara. Hasil penelitian Resepsi Masyarakat Yogyakarta terhadap Pesan Halal dalam iklan Fresh Care di televisi menunjukkan adanya tiga kategori penerimaan pesan yaitu : hegemoni dominan, negosiasi dan opposisi.
\end{abstract}

Kata Kunci: analisis resepsi; iklan FreshCare; masyarakat Yogyakarta

\section{SOCIETY RECEPTION OF HALAL MESSAGES ON FRESHCARE ADVERTISING}

\begin{abstract}
The subject used in this FreshCare ad research talks about the message contained in the ad. Initially the FreshCare ad was aired by Brand Ambassador Agnes Monica and was later replaced by Brand Ambassador Dewi Sandra, which showed that FreshCare passed the halal certification by showing and explaining the existence of the halal label in the $a d$. Thus this research was conducted to determine public acceptance of halal messages. The target people interviewed used in this study were the majority of people in Yogyakarta. In theory, this research wants to know the public reaction to the reception of halal messages contained in FreshCare advertisements describing products and halal products by displaying halal labels by the Indonesian Ulama Council (MUI).Revealing the existence of halal messages in FreshCare advertisements to public message reception in Yogyakarta, various types of message reception which are divided into several types and conclusion methods will be examined with qualitative descriptive methods with Agnes Monica, Dewi Sandra and second versions of FreshCare advertisements. Data collection is done by indepth interviews, documentation, notes, and voice recorders. Yogyakarta public acceptance research results on halal messages in FreshCare advertisements on television show that there are three categories of message reception namely: Domination of Hegemony, Negotiations and Opposition.
\end{abstract}

Keywords: acceptance analysis; FreshCare advertisement; Yogyakarta society 
Korespondensi: Nurma Tri Amalia. Universitas Ahmad Dahlan. Jalan Ringroad Selatan, Tamanan, Banguntapan, Yogyakarta. No. HP, WhatsApp: $\mathbf{0 8 5 2 6 3 0 1 0 1 4 5 ~ E m a i l : ~ i n d a h . w e n e r d a @ ~ c o m m . u a d . a c . i d ~}$

PENDAHULUAN

Periklanan merupakan salah satu bentuk komunikasi dalam menyebarluaskan sebuah informasi mengenai suatu produk di suatu perusahaan. Melalui periklanan informasi disebarluaskan kepada masyarakat guna menentukan keberhasilan penjualan suatu produk. Oleh karena itu, periklanan dapat dikatakan sebagai hal yang terpenting dalam penyebaran informasi suatu produk.

Iklan merupakan kata dasar dari periklanan dapat dikatakan sebagai media yang digunakan oleh sebuah perusahaan dalam hal berbagai tujuan seperti mengingatkan, membujuk, serta mempengaruhi dan memberikan informasi. Kegunaan iklan yang paling penting yaitu membujuk, dalam hal ini proses sebuah periklanan biasanya menggunakan seorang model yang dianggap baik dalam iklan, dimana model tersebut ditampilkan di dalam iklan mampu menarik perhatian pemirsa di televisi.

Media merupakan salah satu hal yang terpenting di dalam iklan, karena dengan adanya sebuah media dapat membantu keberhasilan sebuah iklan dalam dunia periklanan. Iklan biasanya ditampilkan melalui beberapa media diantaranya : media cetak dan media elektronik. Salah satu media yang sering digunakan yaitu media televisi.

Televisi merupakan salah satu media komunikasi yang berbentuk audiovisual (dapat dilihat dan dapat didengar). Oleh karena itu, dengan media televisi iklan dapat disampaikan melalui pesan yang terkandung dalam sebuah iklan. Dengan hal ini, iklan yang disampaikan akan dapat mudah dan cepat diterima oleh masyarakat.

Iklan yang tampil dengan media televisi, dapat dilihat bagaimana kejelasan mulai dari penggunaaan produk, kemasan produk, bentuk produk, serta cara pemakaian produk.

Dunia periklanan pada saat ini semakin berkembang pesat, sehingga dapat membuat persaingan dalam mengiklankan suatu produk. Oleh karena itu, penampilan sebuah iklan ditampilkan dengan sekreatif mungkin supaya dapat menarik perhatian konsumen. Beberapa perusahaan pada saat ini menciptakan produk yang memiliki banyak manfaat, seperti balsem, salep, minyak angin dll. Dari beberapa produk kesehatan diatas merupakan contoh produk yang berfungsi untuk mengobati berbagai macam penyakit seperti pusing, flu, sakit perut dll.

Produk kesehatan merupakan salah satu produk yang dapat meringankan serta mengobati penyakit. Pada saat ini produk-produk kesehatan semakin banyak jenisnya danmasing-masing memiliki manfaat bagi manusia.

Salah satu produk kesehatan yang memiliki banyak manfaat (multifungsi) adalah minyak angin FreshCare. Minyak angin FreshCare merupakan salah satu produk kesehatan yang ditayangkan di televisi, yang memiliki berbagai manfaat untuk meringankan rasa sakit. 


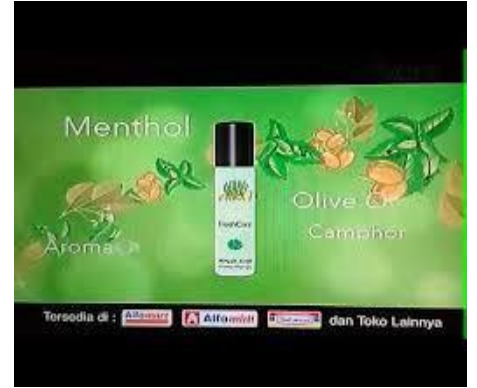

Gambar 1.1

Sumber : freshcare.co.id

Kehalalan suatu produk merupakan hal terpenting dan perlu diketahui oleh masyarakat, sesuai dengan keadaan masyarakat di wilayah Yogyakarta sebagian besar beragama Islam. Dengan demikian, masyarakat perlu adanya kepastian dan keyakinan bagi setiap produk, baik itu makanan ataupun obat-obatan dengan adanya label sertifikasi Halal yang biasanya tertera pada kemasan produk FreshCare. Minyak angin FreshCare merupakan satu-satunya produk minyak angin yang berani untuk mengungkapkan kata Halal. Dalam iklan FreshCare ditampilkan oleh seorang brand ambassador berhijab yaitu Dewi Sandra, dan pada saat iklan FreshCare ditampilkan terdapat kata " Iya kan cuma FreshCare yang bersertifikat Halal".

\section{METODE PENELITIAN}

Pada penelitian menggunakan penelitian kualitatif yang berfokus pada analisis resepsi. Analisis resepsi merupakan proses dimana pesan yang disampaikan oleh media dapat diterima dengan baik oleh khalayak. Dengan metode ini penerimaan pesan dapat diterima dengan baik melalui media oleh khalayak aktif. Subjek penelitian ini adalah iklan FreshCare.Masyarakat di wilayah Yogyakarta merupakan objek yang diambil dan dijadikan sebagai narasumber.
Masyarakat yang dijadikan narasumber adalah mereka yang ber usia 20-50 tahun dan beragama Islam. Penelitian ini dilaksanakan pada bulan Agustus hingga November 2019.

Pengumpulan data dilakukan dengan cara mengumpulkan data primer dimana pengumpulan datanya dilakukan dengan dokumentasi iklan yang diambil dari Youtoube dan dilakukan wawancara terstruktur dimana pada saat melakukan penelitian pewawancara memberikan beberapa pertanyaan kepada responden yang terkait dengan iklan FreshCare yang menggunakan brand ambassador terkenal Dewi Sandra ( perempuan berhijab ) serta penggunaan tagline halal pada produk FreshCare yang dilakukan secara langsung (face to face).

\section{HASIL DAN PEMBAHASAN}

Tampilan iklan FreshCare yang muncul mulai tahun 2011 hingga tahun 2018 terdapat perubahan Brand Ambassador.Mulanya Agnes Monica saja, kemudian ada iklan berikutnya ada versi Dewi Sandra.Pada tahun 2018 hingga sekarang ini iklan FreshCare ditampilkan kedua brand ambassador yaitu Agnes Monica berkolaborasi dengan Dewi Sandra. Setelah adanya iklan FreshCare versi Agnes Monica dan Dewi Sandra yang kemudian iklan tersebut divisualisasikan kedua-duanya serta penggunaan tagline halal, penelitian ini menjelaskan respon masyarakat terhadap kehadiran dua brand ambassador Agnes Monica dan Dewi Sandra dan penggunaan tagline halal tersebut.

Penelitian ini menggunakan analisis data tentang resepsi yang diambil menggunakan analisis menurut Stuart Hall. Analisis yang digunakan melalui penerimaan pesan oleh 
khalayak terhadap pesan yang disampaikan oleh media. Dalam hal ini khalayak dianggap aktif oleh media sebagai penerima pesan $\backslash$. Penelitian ini dilakukan untuk mendapatkan data yang diperoleh dari khalayak terhadap pesan yang disampaikan oleh media.

Dengan adanya khalayak sebagai penonton yang aktif, memaknai sebuah pesan yang disampaikan media dimaknai dengan adanya model encoding/decoding. Khalayak yang dituju sebagai narasumber kami yaitu masyarakat yang mengetahui iklan produk minyak angin FreshCare dan masyarakat yang pernah memakai produk FreshCare serta khalayak yang sudah memasuki usia 20-50 tahun. Khalayak yang dituju sebagian besar beragama islam, karena pada penelitian ini tertuju pada pesan Halal pada iklan FreshCare

Berikut ini hasil wawancara mengenai resepsi masyarakat terhadap pesan Halal yang tercantum dalam iklan FreshCare versi Dewi Sandra:

\section{Gigih Taufiq Ismail}

Wawancara pertama dilakukan oleh Gigih Taufiq Ismail, usia 25 tahun. Gigih merupakan lulusan Universitas Islam Negeri Sunan Kalijaga tahun 2018 program studi ilmu komunikasi, Fakultas Adab dan Ilmu budaya Islam. Gigih bekerja di SMK pada mata pelajaran Sejarah Islam. Gigih aktif dalam beberapa organisasi Muhammadiyah, seperti: Ikatan Mahasiswa Muhammadiyah dan Angkatan Muda Muhammadiyah.

Menurut Gigih dengan ditambahkannya brand ambassador dalam iklan FreshCare membuat iklan yang ditampilkan akan terlihat semakin menarik dan menurutnya kemungkinan besar produk yang dipasarkan akan menjadi lebih laku dalam penjualannya. Adanya perubahan iklan yang awalnya hanya dibintangi oleh Agnes Monica lalu kemudian ditambahkan dengan adanya Brand Ambassador Dewi Sandra, adanya pengucapan label Halal karena dari $80 \%$ masyarakat di Indonesia dapat dilihat beragama muslim, sehingga menurut Gigih itu bagus sekali karena produk FreshCare ini berani mengatakan bahwa produk nya Halal kepada masyarakat melalui media.

"Adanya label Halal akan diterima oleh masyarakat muslim, produk ini diberi label Halal agar menambah kemantapan seorang konsumen untuk menggunakan produk tersebut." (Wawancara Gigih 14 September 2019).

Pendapat Gigih mengenai pesan Halal, dengan adanya pesan pesan tersebut pasti akan diterima oleh masyarakat di Indonesia yang sebagian masyarakatnya beragama Islam. Dengan adanya pesan Halal ini dapat menambah kemantapan masyarakat untuk menggunakan produk FreshCare ini.

\section{Bu Zuhro}

Wawancara yang kedua dilakukan dengan Zuhro seorang pegawai negeri sipil di lembaga Sandi Negara yang berada di wilayah Yogyakarta. Zuhro ini tinggal di Yogyakarta bagian utara di wilayah kabupaten Sleman.

$\mathrm{Bu}$ Zuhro mengatakan bahwa dengan adanya iklan Versi Dewi Sandra itu adalah transformasi yang mencerminkan bahwa masyarakat yang beragama Islam banyak yang menggunakan produk FreshCare. Menurut Bu Zuhro mengenai iklan FreshCare Versi Agnes Monica dan Dewi 
Sandra bagus, Iklan FreshCare lebih menunjukkan kehalalan produk FreshCare.

"Adanya tagline Halal dan ditambahan Brand Ambassador Dewi Sandra dalam iklan FreshCare ini menurutku penting karena kedua - dua nya dapat mempengaruhi penjualan produk FreshCare yang akan mengalami peningkatan ". (Wawancara Zuhro 17 September 2019)".

Menurut Zuhro adanya tagline Halal yang muncul bersamaan dengan munculnya Brand Ambassador Dewi Sandra ini penting karena dengan adanya kedua nya penjualan produk FreshCare akan mengalami peningkatan.

3. Nararia Ayu Wijayanti

Wawancara yang ketiga dilakukan dengan Nararia Ayu Wijayanti, biasa dipanggil Ara. Usia 20 tahun pekerjaan ibu rumah tangga sekaligus guru di Taud ( Tahfidz Anak Usia Dini). Ara merupakan salah satu masyarakat yang menggunakan minyak angin FreshCare.

Iklan Freshcare versi Dewi Sandra lebih menyakinkan bagi Ara bahwa percaya minyak angin FreshCare ini Halal dan aman digunakan oleh masyarakat. Selain itu menurut Ara iklan versi Agnes Monica yang pada saat itu sedang naik daun sehingga penyampaian pesan yang ditayangkan oleh Agnes Monica akan mudah tersebar menjadi Go Internasional. Sedangkan untuk yang versi Dewi Sandra jadi lebih meyakinkan masyarakat atas kehalalan FreshCare yang dibuktikan dengan hadirnya Brand Ambassador Dewi Sandra.

Menurut Ara mengenai pesan Halal dalam iklan FreshCare versi Dewi Sandra, lebih menunjukkan kehalalan FreshCare dengan memperlihatkan label Halal dari MUI (Majelis Ulama Indonesia).

"Adanya tagline Halal ini penting untuk membentuk kepercayaan pelanggan bahwa produk tersebut terjamin kehalalannya, apalagi dengan adanya Dewi Sandra seorang modeling berhijab sebagai brand ambassador FreshCare".

Menurut Ara adanya tagline halal penting karena dapat membentuk kepercayaan pelanggan bahwa produk FreshCare ini tidak diragukan lagi kehalalannya, ditambah dengan adanya Dewi Sandra sebagai brand ambassador dalam iklan FreshCare.

\section{Hermawan Cahyo}

Wawancara keempat dilakukan dengan Hermawan Cahyo biasa dipanggil Iwan, Usia Iwan 21 tahun. Iwan merupakan alumni Universitas Gadjah Mada program studi Teknik kejuruan, Fakultas Teknik dan disco Advokasi. Kegiatan sehari - hari menjadi guru mengajar mengaji dan mengajar di keilmuan lain.

Menurut Iwan iklan versi Agnes Monica melihatnya dari segi mengenai fungsi FreshCare,sementara versi Dewi Sandra menurut lebih menekankan adanya pesan Halal, sehingga dapat meyakinkan bahwa produk FreshCare itu Halal. Hal ini terjadi karena melihat masyarakat yang mayoritas beragama muslim.

"Adanya tagline halal menunjukan bahwa produk yang dibuat benar-benar terbuat dari bahan yg halal sehingga menambah kepercayaan masyarakat khususnya Indonesia yg mayoritas Islam untuk dapat memakainya dengan aman. Dan sosok Dewi Sandra sebagai muslimah menambah keyakinan masyarakat bahwa produk tersebut halal dan 
aman dipakai oleh kaum muslim di Indonesia".(Wawancara Iwan 17 September 2019)".

Menurut pendapat Iwan mengenai penting nya tagline Halal menunjukkan bahwa produk yang dibuat terbukti kehalalannya dan keberadaan Dewi Sandra sebagai brand ambassador pengganti Agnes Monica menurut Iwan dapat menambah keyakinan masyarakat bahwa produk FreshCare Halal dan aman untuk digunakan.

\section{Bunga}

Wawancara kelima dilakukan dengan Bunga, yang merupakan salah satu dosen di perguruan tinggi negeri Yogyakarta. Bunga mengajar salah satu mata kuliah di perguruan tinggi negeri tersebut.

Menurut Bunga mengenai iklan yang ditayangkan oleh Agnes Monica lebih menyasar semua segmen masyarakat, lain halnya iklan versi Dewi Sandra yang mengatakan kehalalan produk.Menurut Bunga iklan ini mengambil momentum hijrah yang saat ini sedang tren, sehingga iklan yang ditampilkan Dewi Sandra menjadi pesona yang religius. Seakan-akan iklan ini menjadikan produk FreshCare berbeda dengan produk lain yang menonjolkan kehalalan produknya.

"Kalau aku melihat lebih ke komodifikasi Halal nya ya, jadi sekarang klaim Halal itu menjadi sebuah produk yang dijual gitu, jadi kayak jilbab di brand Halal, kemudian deterjen di brand Halal padahal produk lain mungkin diproduksi dengan tidak Haram tetapi ketika ada brand Halal ini orang orang jadi kepikiran untuk tertarik untuk membeli." (Wawancara Bunga 18 September 2019).
Bunga menilai dengan melihat adanya komodifikasi halal yang ditempelkan pada produk yang dijual, dan menurutnya dengan adanya brand Halal itu orang-orang jadi tertarik untuk membeli.Menurut Bunga penggunaan label halal memperkuat informasi bahwa Freshcare adalah produk halal. Dengan adanya tagline Halal yang disertai dengan keberadaan Dewi Sandra sebagai pengganti Brand Ambassador Agnes Monica, dapat memperkuat branding Halal produk karena dengan adanya kehadiran Dewi Sandra cukup sesuai dengan produk yang di iklankan karena Dewi Sandra beragama muslim, wanita yang mengenakan hijab, selain itu Dewi Sandra juga mempunyai daya tarik tersendiri.

\section{Dwi Halimah}

Wawancara keenam dilakukan dengan Dwi Halimah, biasa dipanggil Dwi. Dwi ini merupakan salah satu mahasiswa Universitas Islam Negeri Sunan Kalijaga, Fakultas Saintek, program studi biologi semester akhir. Usia Dwi saat ini 22 tahun. Dwi Berasal dari Kebumen Jawa Tengah. Dwi memiliki kesibukan menyelesaikan tugas akhir sebagai syarat kelulusan nya.

Menurut pendapat Dwi adanya iklan versi Dewi Sandra dalam iklan FreshCare menunjukkan dan menekankan bahwa produk FreshCare Halal dengan demikian mampu membuat daya tarik pembeli terutama masyarakat muslim di Indonesia.Dwi mengatakan bahwa dirinya bahwa label Halal itu juga bisa dibeli. Tapi dirinya yakin bahwa produk FreshCare halal dengan adanya pesan Halal yang ditunjukkan dengan label halal pada saat iklan ditayangkan. 
"keberadaan tagline halal sangat penting sebagai daya tarik masyarakat Indonesia yang mayoritas penduduknya muslim, dan kehadiran Dewi Sandra sebagai brand ambassador yang menggantikan Agnes Monica sangat mendukung label Halal yang ada. Sehingga masyarakat akan lebih percaya jika memang orang muslim juga yang mengiklankan, apalagi seorang Dewi Sandra memiliki Brand image yang baik di mata masyarakat". (Wawancara Dwi 16 September 2019)"

Menurut Dwi adanya tagline halal sangat penting, karena dapat menambah daya tarik masyarakat di Indonesia yang mayoritas masyarakatnya muslim, selain itu menurut Dwi ditambahkan nya brand ambassador Dewi Sandra yang ditampilkan sebagai pengganti Agnes Monica, sangat mendukung adanya label Halal yang ada. Menurutnya kehadiran Dewi Sandra maka masyarakat di Indonesia akan lebih percaya jika yang mengiklankan FreshCare Dewi Sandra yang memiliki image yang baik di mata masyarakat.

7. Ahmad Mufarid Al Mubarok

Wawancara ketujuh dilakukan dengan Ahmad Mufarid Al mubarok biasa dipanggil Farih, mahasiswa Universitas Negeri Sunan Kalijaga, Fakultas sosioluting dan pemikiran islam. Ahmad pada saat ini sedang sibuk perkuliahan di semester 5. Selain kuliah, kegiatan lain yang dilakukan oleh Ahmad yaitu membaca buku di perpustakaan.

Menurut Ahmad label halal yang ditampilkan di iklan FreshCare agama seakan - akan dijadikan branding pada iklan. Kemudian adanya iklan FreshCare versi Dewi Sandra ini ditampilkan menggunakan pesan halal karena melihat kondisi di Indonesia yang mayoritas beragama islam, selain itu iklan ini karena pengaruh adanya trend Hijrah yang lagi populer saat ini. Iklan FreshCare versi Dewi Sandra juga dianggap sebagai komodifikasi agama yang dijadikan sebagai alat jualan.

Menurut Ahmad pesan halal tidak terlalu penting untuk produk kesehatan yang dipakai di luar tubuh seperti Freshcare, kecuali kalau makanan perlu adanya label Halal yang di tampilkan.

\section{Wening Niki Yuntari}

Wawancara kedelapan dilakukan oleh narasumber bernama Wening Niki Yuntari, biasanya dipanggil Wening. Usia 23 Tahun. Wening ini sedang sibuk kuliah di Universitas Negeri Yogyakarta, Program studi pendidikan guru sekolah dasar semester akhir. Selain kesibukan kuliah, dia memiliki kesibukan di rumah yaitu menjadi pembimbing belajar bagi anak - anak sekolah dasar. Selain dengan kesibukan nya,Wening ini juga aktif dalam berbaur di organisasi di kampung nya.

Pendapat Wening mengenai keberadaan pesan Halal itu berlebihan, karena menurutnya adanya tampilan kata halal pun dirinya tetap memakai produk tersebut, karena khasiat yang ada pada Freshcare. Wening juga merasa dengan kehalalan produk inikarena sedang menyesuaikan dengan keadaan yang ada di Indonesia yang $80 \%$ beragama Islam.Wening meyakini bahwa perusahaan tidak mungkin mengeluarkan produknya yang tidak halal, karena khawatir produk yang dijual tidak laku. 
9. Norma Sari Indah

Wawancara Kesembilan dilakukan dengan Norma Sari Indah, mahasiswa pendidikan guru sekolah dasar di Universitas Ahmad Dahlan Yogyakarta semester akhir. Norma pada saat ini memasuki usia 23 tahun. Di usia yang masih terbilang muda ini Norma ini dapat dikatakan hebat dia memiliki dua kesibukan yaitu selain menjadi mahasiswa tingkat akhir, Norma juga mengisi kesibukan di rumahnya dengan membuka tempat bimbingan belajar bagi anak sekolah dasar, dia berperan sebagai pengajar pada semua mata pelajaran anak sekolah dasar.

Menurut Norma mengenai adanya kata Halal dan keberadaan Dewi Sandra dalam iklan FreshCare, adanya pesan Halaldan keberadaan Dewi Sandra dapat menambah keyakinannya saat akan membeli produk FreshCare dan Norma merasa tidak ada keraguan lagi ketika memilih produk FreshCare.

"Bagus donk, dengan adanya pesan Halal dapat menambah keyakinan saya ketika membeli produk Freshcare".

"Menurutku itu penting adanya Dewi Sandra yang berhijab dan Tagline Halal karena kedua nya saling berkaitan, menjadikan saya merasa yakin akan adanya kehalalan pada produk FreshCare tersebut" (Wawancara Norma 8 September 2019).

\section{Yuhana Febrianti}

Wawancara kesepuluh dilakukan dengan Yuhana Febrianti dengan nama panggilan Yuha. Yuha adalah mahasiswa di Universitas Islam Negeri Malang dan beragama Islam. Pada saat ini Yuhana sedang menempuh semester 7 program studi hukum, dan beragama Islam.
Menurut Yuha adanya tagline halal disertai dengan brandambassador Dewi Sandra yang dalam iklan FreshCare ini akan menambah kemantapan dalam menggunakan FreshCare bahwa produknya aman dipakai.

"sebagai seorang muslim, saya rasa ini akan jadi lebih mantap dan yakin bahwa FreshCare aman dengan adanya tagline Halal yang disertai dengan munculnya Dewi Sandra sebagai Brand Ambassadornya".( Wawancara Yuhana 13 September 2019).

Berdasarkan wawancara yang dilakukan melalui beberapa narasumber, berikut ini hasil wawancara dari sepuluh narasumber yang terdiri dari Bunga, Ara, Gigih, Wening, Iwan, Norma, Dwi, Bu Zuhro, Ahmad, dan Yuhana. Dari sepuluh narasumber ini mempunyai pemikiran masing - masing mengenai pesan yang ada dalam iklan FreshCare versi Dewi Sandra dengan baik dan menginterpretasikan iklan dengan pemikiran masing-masing. Dalam penelitian ini untuk mengklarifikasi narasumber melalui wawancara dengan menggunakan tiga posisi yang terkait dengan teori Stuart Hall sebagai berikut:

\section{Hegemoni Dominan}

Hall menjelaskan bahwa situasi dimana media menyampaikan pesan, sedangkan khalayak yang menerima terhadap isi pesan yang disampaikan oleh media. Ketika media menyampaikan pesan, khalayak sebagai penerima, melakukan penerimaan dengan baik. Terkait dengan wawancara yang dilakukan oleh beberapa narasumber, maka sebagai peneliti dapat menyimpulkan bahwa: Gigih, Bu Zuhro, Ara, Iwan, Dwi, Norma, dan Yuhana termasuk dalam kategori dominant hegemonic. 


\section{Negotiated}

Pada posisi ini dapat disimpulkan bahwa khalayak dapat menerima karena adanya suatu alasan tertentu. Hal ini sesuai dengan pemikiran Bunga yang memiliki tanggapan mengenai iklan FreshCare bahwa mereka secara tidak langsung menerima pesan yang disampaikan oleh iklan FreshCare mereka merasa menanggapi iklan FreshCare ini biasa saja.

\section{Oposisi}

Pada posisi ini audiens menolak makna pesan yang dimaksudkan atau disukai media dan menggantikannya dengan cara berfikir sendiri terhadap topik yang disampaikan oleh media. Wening dan Ahmad yang menganggap adanya pesan halal ini menjadi berlebihan pada Iklan Freshcare. Menurut Wening pesan Halal itu memang bagus, akan tetapi terlalu berlebihan karena tidak adanya cap Halal pasti orang yang membutuhkan dari minyak angin itu karena manfaat nya bukan cap atau label Halal nya.Sementara Ahmad menganggap adanya pesan ini Halal seakan - akan agama menjadi branding.

\section{SIMPULAN}

Berdasarkan hasil penelitian yang dilakukan menyatakan bahwa sebagian besar dari kesepuluh informan yang ditemukan dalam penelitian melakukan penerimaan dengan baik mengenai keberadaan Dewi Sandra dan pengucapan tagline halal itu penting disampaikan dalam iklan FreshCare, mengingat keberadaan masyarakat di Indonesia yang sebagian besar beragama Islam menempati tiga penerimaan pesan diantaranya tujuh informan menempati pada posisi dominan Hegemoni, satu informan menempati negosiasi dan dua informan menempati oposisi. Hal dikarenakan karena latar belakang informan yang berbeda-beda yang kemudian mempengaruhi penerimaan pesan.

\section{DAFTAR PUSTAKA}

Andersen, K.E. (1972). Introduction to Communication Theory and Practice. Menio Park, Ca.: Cummings Publishing Company.

Effendy, Onong Uchyana. (2013). Ilmu Komunikasi Teori dan Praktek. PT Remaja Rosdakarya.

Hall, Stuart. (2007). Cultural Studies and The Center dalam Richard West dan Lynn H, Tumer, Introduting Communication Theory : Mc. Graw Hill.

Jaiz, Muhammad. (2014). Dasar - Dasar Periklanam. Graha Ilmu: Yogyakarta.

Junus, Umar. (1985). Resepsi Sastra Sebuah Pengantar. PT Gramedia : Jakarta

Liliweri, Alo. (2011). Komunikasi Serba Ada Serba Makna. Jakarta : Kencana.

Morrison. (2013). Teori Komunikasi Individual Hingga Massa. Kencana Prenadamedia Grub.

Mulyana, Dedy. Ilmu Komunikasi Suatu Pengantar. PT Remaja Rosdakarya:Bandung.

Nurudin. Pengantar Komunikasi Massa. PT Raja Grafindo Persada : Jakarta.

Oktarina,Yetty. (2017). Komunikasi Dalam Perspektif Teori dan Praktik. CV Budi Utama: Yogyakarta.

Rahmat, Jalaludin. (2009). Psikologi Komunikasi. Cetakan XXVII. PT Remaja Rosdakarya : Bandung.

Sugiyono. (2016). Metode Penelitian Kuantitatif, Kualitatif, dan $R \& D$. ALFABETA : Bandung.

Wasito, hermawan. 1995. Pengantar Metodologi Penelitian. PT Gramedia Pustaka Utama : Jakarta.

\section{Artikel dari website tanpa nama penulis}

FreshCare Minyak Angin Aromatherapy, Diakses dari http://freshcare.co.id/ 
About Ultra Sakti, Diakses dari https://www.ultrasakti.com/about-us/\#

\section{Jurnal online}

Yuniyanto, H.R.., Sirine, Hani. (2018). Pengaruh Iklan terhadap Minat Beli Pengguna Youtube dengan Brand Recognition sebagai Variabel Intervening, 8(1), DOI: 10.15408/ess.v8i1.5885 